\title{
Monitoring ecological representation in currently non-harvestable areas: Four British Columbia case studies ${ }^{1}$
}

\author{
by David J. Huggard², Glen B. Dunsworth², Jim R. Herbers ${ }^{3}$, Walt Klenner ${ }^{4}$, Laurie L. Kremsater ${ }^{1}$ and Robert Serrouya ${ }^{5}$
}

\begin{abstract}
We evaluated representation of ecosystem types in non-harvestable areas within managed forests, as a coarse-filter indicator for biodiversity monitoring, with four case studies in British Columbia: Weyerhaeuser's coastal tenure, Clayoquot Sound on western Vancouver Island, Arrow Lakes in southwestern B.C. and Okanagan highlands of south-central B.C. Representation of some coarser- and finer-level ecosystem units was poor in the two studies with lower amounts of nonharvestable area, and more equitable in the two studies with more diverse harvesting constraints. Under-representation of highly productive sites and high proportions of edge area were concerns for most ecosystems. Representation would be improved with the addition of proposed new reserves in two of three study areas. We discuss specific management implications and broader recommendations for monitoring representation, including the need for regional analyses, tests with habitat structures and organisms, effects of other disturbances and updating monitoring results.
\end{abstract}

Key words: biodiversity monitoring, ecological indicators, ecosystem representation, landscape planning, unmanaged areas

\section{RÉSUMÉ}

Le niveau de représentativité des types d'écosystèmes dans les zones inexploitables de forêts aménagées a été évalué en tant qu'indicateur à filtre brut afin de faire un suivi de la biodiversité dans quatre études de cas en Colombie-Britannique: le territoire côtier de Weyerhaeuser, la Baie Clayoquot sur la côte Ouest de l'Île de Vancouver, les Lacs Arrow au sud-ouest et les plateaux de l'Okanagan au centre-sud de la province. Les deux sites ayant les plus petites superficies d'aires inexploitables avaient une représentativité relativement faible tant au niveau du filtre brut que fin. En revanche, les deux sites ayant des contraintes d'exploitation plus variées ont démontré une meilleure représentativité. Le manque de représentation d'aires à forte productivité et la proportion élevée en superficie de lisières sont des aspects préoccupants dans la plupart des écosystèmes. La représentativité pourrait être accrue en aménagent de nouvelles réserves dans deux des trois sites d'étude. Nous discutons d'implications spécifiques concernant l'aménagement et de recommandations générales sur le suivi de la représentativité, incluant le besoin d'analyses régionales, de tests avec les structures d'habitat et les organismes, des effets d'autres perturbations et la mise à jour des résultats des suivis.

Mots clés : suivi de biodiversité, indicateurs écologiques, représentativité, planification du paysage, aires non aménagées

\section{Introduction}

Ensuring that ecosystems or habitats are represented in an unmanaged state has been a well-recognised coarse-filter component of strategies to conserve biodiversity since UNESCO's Man and the Biosphere program in 1970 (UNESCO 1974, Austin and Margules 1986, Pressey et al. 2000, Scott et al. 2001a). Ecologically representative unmanaged areas are central to an effective program to maintain biodiversity in forested landscapes (Lindenmayer et al. 2000), contributing to the maintenance of the thousands of species that are too poorly known to manage on an individual basis (Margules and Usher 1981, Scott et al. 2001a). They also act as a safeguard against inevitable uncertainty in maintaining species in the managed part of the landbase (Lindenmayer $e t$ al. 2000). Larger representative unmanaged areas can act as ecological baselines, against which to compare human effects on the rest of the landbase (Arcese and Sinclair 1997). Biodiversity monitoring involves many indicators (Noss 1999, Pressey 2004), but ecological representation is a top priority in complex, poorly studied regions or when poorly known organisms are of concern (Austin and Margules 1986, McKenzie et al. 1989, Margules and Pressey 2000).

In complex managed landscapes, operational and regulatory constraints on timber harvest - such as physical inaccessibility, steep or unstable slopes, riparian reserves, scenic landscapes, recreation areas, or reserves for featured species - often ensure that the amount of land unavailable for harvest exceeds the area in officially designated protected areas (e.g., DeVelice and Martin 2001, Strittholt and DellaSala 2001). These non-harvestable areas make long-term contri-

\footnotetext{
${ }^{1}$ Presented at the 5th North American Forest Ecology Workshop, Gatineau, Quebec, June 2005.

${ }^{2}$ Forest Sciences Department, University of British Columbia, 2424 Main Mall, Vancouver, B.C. V6T 1Z4. E-mail: huggard@interchange.ubc.ca

${ }^{2}$ Glen Dunsworth Ecological Consulting, 7857 Shangri-la Rd., Lantzville, B.C. V0R 2H0.

${ }^{3}$ Department of Biological Sciences, University of Alberta, Edmonton, Alberta T6G 2E9.

${ }^{4}$ B.C. Ministry of Forests, 515 Columbia St., Kamloops, B.C. V2C 2T7.

${ }^{5}$ Serrouya and Associates, Box 1522, Revelstoke, B.C. V0E 2 S0.

${ }^{3}$ North Island Timberlands, Weyerhaeuser. 65 Front St., Nanaimo, B.C. V9R 5H9.
} 


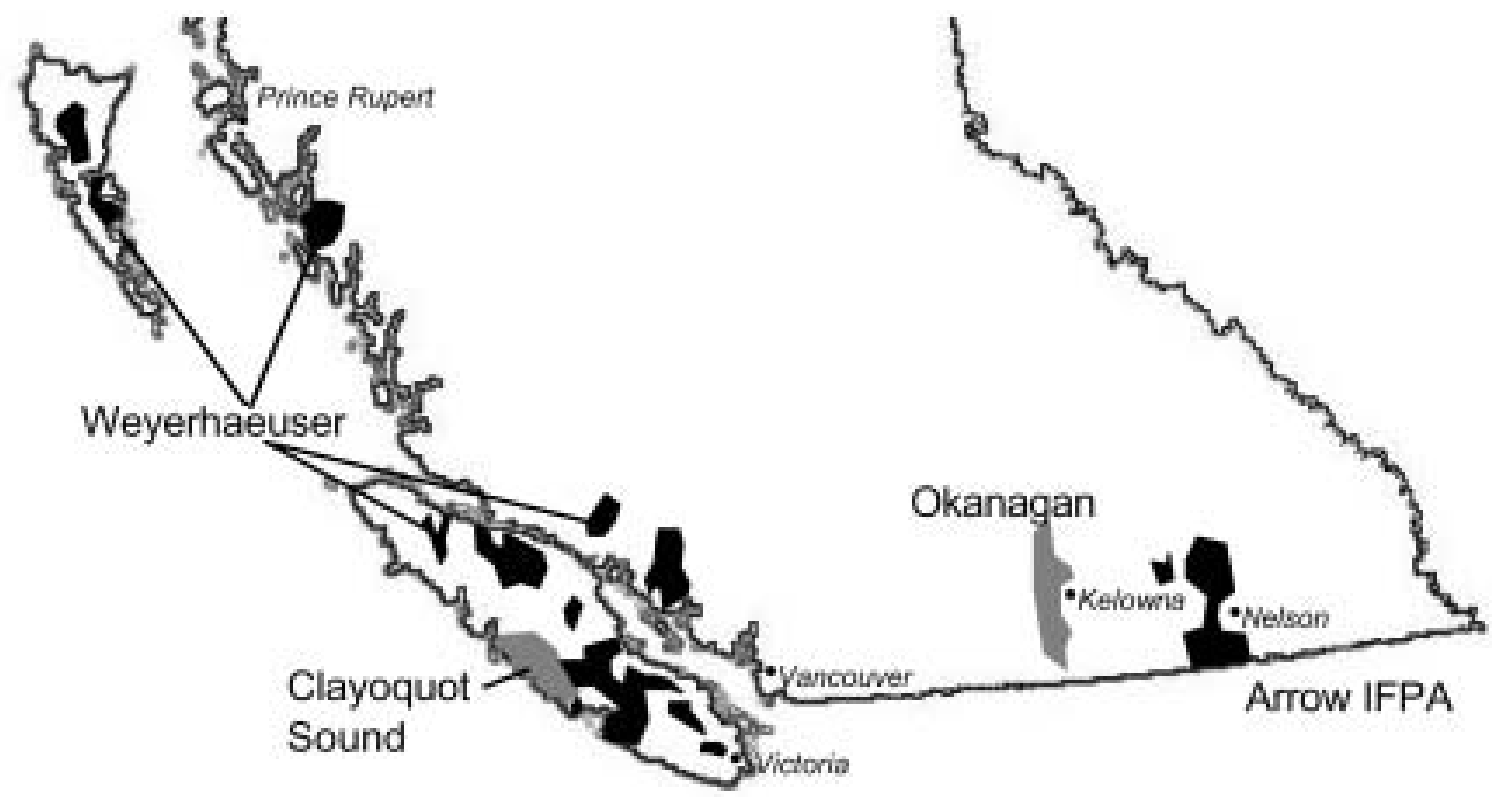

Fig. 1. Location of four case study areas in southern British Columbia.

butions as areas not subject to timber harvest and form important core areas for landscape conservation planning (Noss et al. 1999). However, the constraints producing nonharvestable areas in managed forests may lead to low representation of some ecosystem types, reducing the contribution of non-harvestable areas to maintaining the entire suite of biological diversity (Margules and Pressey 2000). The primary question for monitoring non-harvestable areas in managed forests is therefore how representative those areas are of the ecosystems in the landbase.

In addition to ecosystem representation, several other characteristics of non-harvestable areas can affect their ecological contribution and should be included in the monitoring of non-harvestable areas: 1) Size and shape of non-harvestable patches, especially where negative edge effects from adjacent managed stands could compromise the ability of unmanaged areas to fulfill some of their ecological roles (Harris 1988, Kremsater and Bunnell 1999). 2) Larger-scale spatial aspects. Geographic distribution of unmanaged areas is needed to represent localized species, particularly where ecosystem types are broadly defined (Scott et al. 2001b). Other aspects of spatial patterning of non-harvestable areas likely affect their function, but practical monitoring is difficult because map-based indices of pattern are of uncertain relevance to organisms (Lindenmayer et al. 2002) or entail species-specific components (e.g. "connectivity"; Beier and Noss 1998, Richards et al. 2002). In practice, we rely on visual evaluation of maps of non-harvestable areas, which we do not present in this summary paper. 3) Productivity. Within ecosystem types, low productivity sites may form a disproportionate part of non-harvestable areas, reducing the value for organisms dependent on high productivity sites (Stokland 1997, Mendel and Kirkpatrick 2002). 4) Permanence. Compared to official protected areas, some operationally constrained forest may be a less certain long-term source of non-harvestable areas. For example, physically or economically inoperable areas may become suitable for harvest when technology or markets change.

In this paper, we summarize case studies of monitoring ecosystem representation of non-harvestable areas and some of the other characteristics listed above, from four areas in British Columbia: Weyerhaeuser's coastal B.C. tenure (which has subsequently undergone several ownership changes after our 2003 analysis), the Arrow Innovative Forest Practices Agreement (IFPA) area, Clayoquot Sound and the Okanagan dry-belt (Fig. 1). The first two studies were part of broader biodiversity monitoring programs, which included monitoring of habitat structures, landscape features, and indicator organisms; the latter two studies were intended to inform specific land-use decisions. We highlight main results, then discuss broader issues for monitoring non-harvestable areas.

\section{Methods}

Case study 1: Weyerhaeuser coastal British Columbia

Weyerhaeuser's (formerly MacMillan Bloedel; currently Brascan) coastal B.C. tenure covers $1541 \mathrm{~km}^{2}$ of private forest land and $11588 \mathrm{~km}^{2}$ of public forested land across Vancouver Island, in scattered areas on the mainland coast and on Haida Gwai'i (Queen Charlotte Islands). Ecosystems range from drier Douglas-fir (Pseudotsuga menziesii) forests in the flatter areas of southern and eastern Vancouver Island, to rainforests of western redcedar (Thuja plicata) and western 
hemlock (Tsuga heterophylla) on the steeper west coast and in the north, and wet montane forests at higher elevations. Current practices include variable retention harvesting in managed stands, and Old Growth zones intended to occupy $10 \%$ of the tenure (Boyland et al. 2004). Assessment of nonharvestable areas is a coarse-filter indicator in a program to monitor the effectiveness of practices for maintaining biological diversity (Kremsater et al. 2003). Results are intended to improve the ecological effectiveness of management practices, to provide context for land-use planning and to focus the finer-filter monitoring of habitat structures and organisms.

\section{Case study 2: Clayoquot Sound}

Clayoquot Sound includes $2183 \mathrm{~km}^{2}$ of primarily old-growth rain forest on the west coast of Vancouver Island. The area is highly valued by First Nations and environmental groups, and is a UN Biosphere Reserve. Recommendations of the Clayoquot Sound Scientific Panel (1995) led to logging moratoriums in Eehmiis (a Nuu-chah-nulth term meaning "exceptionally precious") areas while detailed watershed management plans were being prepared. With the completion of these plans, government, First Nations, environmental groups and industry are debating the fate of the Eehmiis areas. As one input to this decision, the ecological representation of nonharvestable areas in the current watershed plans and the additional contribution of Eehmiis areas were assessed in a project supported by WWF Canada, Iisaak Forest Resources and International Forest Products.

\section{Case study 3: Arrow IFPA}

The Arrow Innovative Forest Practices Agreement (IFPA) was established by five forestry companies in the Arrow Lakes area of southeastern B.C. The project area of $4056 \mathrm{~km}^{2}$ includes valley-bottom Interior Cedar-Hemlock (ICH; Lloyd et al. 1990) forests dominated by Douglas-fir, western redcedar and western hemlock and upper-elevation Engelmann Spruce (Picea engelmannii) - Subalpine Fir (Abies lasiocarpa) (ESSF; Lloyd et al. 1990) forests. Steep terrain and concerns about many resource values, including scenic landscapes, water and mountain caribou (an ecotype of Rangifer tarandus), result in many overlapping constraints to forest harvesting. In addition to assessing ecosystem representation, and to act as initial checks of the GIS exercise, representation was evaluated at a finer scale using field measurements of habitat structures and winter bird communities. Comparisons were made of non-harvestable and harvestable 100- to 140-year-old stands, in both ICH and ESSF forest.

\section{Case study 4: Okanagan dry-belt}

This study area covers $1349 \mathrm{~km}^{2}$ in dry forest west of Okanagan Lake in south-central B.C. Forests range from Interior Douglas-Fir (IDF) forests bordering on valley-bottom grasslands, through Montane Spruce (MS) forests dominated by seral lodgepole pine (Pinus contorta), to ESSF forests grading into alpine parkland. The area includes proposed protected areas recommended by a public land-use planning process, and additional Old-Growth Management Areas (OGMAs) recommended by government. The analysis examines current non-harvestable area and the incremental contribution of the proposed parks and OGMAs.

\section{Defining ecosystem types for representation analysis}

Distinct ecosystem types for representation analysis would ideally be defined by the assemblages of all organisms they contain. Some complementarity and gap analyses for reserve design take this general approach, but pragmatically use only a restricted subset of species in a limited number of discrete patches of habitat (e.g., trees species in remnant patches of Eucalyptus forest; Margules and Stein 1989). For less discrete habitats, studies have used quantitative multivariate methods based on surveys of indicator organisms to define distinct ecosystem types (DeVelice et al. 1988, Sætersdal and Birks 1993). At larger scales and for poorly known taxa, representation must be based on environmental variables that act as surrogates for the distribution of organisms (McKenzie et al. 1989, Belbin 1993, Johnson 1999, Pressey et al. 2000). Using surrogate variables reduces confidence that all species are included in the resulting representative units (Margules and Stein 1989, Pressey et al. 2000, Kati et al. 2004), but is often a practical necessity.

In British Columbia, the Biogeoclimatic Ecosystem Classification (BEC; Pojar et al. 1987) offers a system of ecosystem units with the practical advantages of available mapping, extensive field sampling and widespread acceptance in the province. The BEC system is hierarchical: "zones" represent major forest types, "subzones" describe different climatic regimes within zones, "variants" encompass different elevational or geographic variation within subzones, and "site series," the finest level of classification, distinguish soil moisture and nutrient regimes within variants, as indicated by the vegetation assemblage. The BEC system allows assessment of representation at a coarser level of surrogate environmental variables (variants), and at a finer level of assemblages of indicator plants (site series). Extensive systematic surveys of a wide range of taxa do not exist in B.C. to assess representation directly at the species level.

BEC variants have been mapped for all the case study areas. Site series mapping based on air-photo interpretation and ground-truthing was available for Clayoquot Sound, except for some park area, and for a $2107 \mathrm{~km}^{2}$ sub-sample area within Weyerhaeuser's coastal B.C. tenure. Site series in the Arrow IFPA and Okanagan areas were mapped using predictive models based on elevation, slope, topography, satellite imagery and other available predictors. Because these predictive models have only moderate success at distinguishing similar site series, groupings of similar site series were used as the finest ecosystem units in the Arrow IFPA and Okanagan studies.

\section{Analysis of representation in non-harvestable areas}

The basic analysis is a GIS overlay of the ecosystem units on the non-harvestable and harvestable landbases, excluding any non-forest area. Representation of each ecosystem type is expressed as the proportion of the total area of the ecosystem type that is non-harvestable. The different types of constraints that produce non-harvestable areas were applied in sequence starting from parks and legal reserves that were most likely to be permanently non-harvestable, followed by areas that were constrained from timber harvesting because they were commercially non-productive or anomalous (often termed "problem forest types" in timber-supply analyses), and inoperable areas. Small, potentially temporary reserves within managed stands were not included. Details of the spe- 
cific constraints varied in each case study area, but this sequential approach allowed us to examine how representation would change if inoperable areas that were not otherwise constrained from harvesting became operable in the future, or if commercially non-productive and anomalous forest types were excluded from the analyses. Care was taken to avoid double-counting areas with overlapping constraints. The case studies used the most current available data on constraints when they were conducted between 2000 and 2004. We note that no forest is inherently "non-harvestable"; nonharvestable areas will change if there are substantial future changes in policy, markets or technology.

The incremental contribution (areas not already constrained from harvesting) of Old-Growth zones on Weyerhaeuser's tenure, Eehmiis areas in Clayoquot Sound and proposed parks and OGMAs in the Okanagan area were assessed by adding these map layers after the existing nonharvestable areas.

Additional analyses for all four study areas examined ecosystem representation in non-harvestable areas in nonanomalous, productive forest only. These analyses were done because of conservation concerns that non-harvestable areas might be predominantly low productivity or anomalous forests, which could be less likely to sustain the full range of biodiversity. In Weyerhaeuser's area, one analysis excluded areas considered non-harvestable because they are commercially non-productive (defined by the company as $<210$ $\mathrm{m}^{3} /$ ha of timber). Another analysis examined only forest with site index $\geq 25 \mathrm{~m}$ (i.e., top height $\geq 25 \mathrm{~m}$ at 50 years). In the Okanagan study, separate analyses examined forests with low $(<14 \mathrm{~m})$, medium $(14-21 \mathrm{~m})$ and high $(>21 \mathrm{~m})$ site indices. Complete site index information was not available for the Arrow IFPA and Clayoquot Sound areas.

Many indices are available for describing the size and shape of patches, which are a key interest for conservation. One measure that is simple enough for broad-scale monitoring and relevant to many biological variables is the amount of edge versus interior area. We calculated interior non-harvestable area by masking out $50-\mathrm{m}$ and $200-\mathrm{m}$ buffers into the non-harvestable landbase. A 50-m distance is a typical maximum edge effect for most biotic variables studied in western forests, while $200 \mathrm{~m}$ is a more extreme distance reported for a few biotic variables in some situations (review in Kremsater and Bunnell 1999). Because we were interested in the longterm characteristics of non-harvestable areas, the buffer distances were applied to the entire edge of the non-harvestable landbase, regardless of the current age of the adjacent stands in the managed landbase. Interior areas are therefore more than $50 \mathrm{~m}$ or $200 \mathrm{~m}$ from a potentially managed stand, whether or not that adjacent stand has actually been harvested.

Additional spatial variables, geographic distribution of non-harvestable areas, seral stages (stand ages) and contributions of partially constrained areas were examined to answer specific questions in the various studies, but, for brevity, these aspects are omitted in this summary.

Habitat structures and winter birds in the Arrow IFPA The four case studies all assessed representation in non-harvestable areas at the coarse level of ecosystem units. In the Arrow IFPA, we also evaluated how representative non-har- vestable areas are at the finer levels of habitat structures and organisms. We compared habitat structures in non-harvestable and harvestable (but not yet harvested) stands using three habitat plots in each of 36 non-harvestable stands and 18 harvestable stands in $\mathrm{ICH}$, and 12 non-harvestable and 12 harvestable stands in ESSF. All stands were 100-140 years old, and were matched by site series grouping between harvestable and non-harvestable landbases. Each habitat plot used nested plots of 0.01 ha for small live trees and 0.04 ha for snags and live trees $\geq 30 \mathrm{~cm}$ diameter, five 2-m diameter subplots for cover layers (canopy, shrub, herb-layer, moss, litter) and two perpendicular 50-m intercept transects for coarse woody debris (CWD) volume (van Wagner 1968).

We also surveyed birds in 12 harvestable and 12 non-harvestable stands in each of the ESSF and ICH in winter 2003, and repeated the ICH surveys in winter 2004. Four to eight unlimited distance point counts spaced $200 \mathrm{~m}$ apart were used in each stand. Detection distance functions were calculated for groups of similar species for each landbase, and used to correct for any biases in detectability among landbases (see Herbers et al. 2004).

\section{Results}

Representation of ecosystems in the non-harvestable landbase Overall percentage of the landbase that was non-harvestable ranged from $22.2 \%$ of the Okanagan drybelt area and $25.7 \%$ of Weyerhaeuser's tenure, to $42.7 \%$ in the more complex topography of the Arrow IFPA, to $61.7 \%$ of the complex and highly regulated Clayoquot Sound (Fig. 2).

Representation of BEC variants in the non-harvestable landbase was fairly equitable in the Clayoquot Sound and Arrow IFPA, because the variety of regulatory and physical constraints affected ecosystems throughout these areas (Fig. $2 \mathrm{~b}, \mathrm{c})$. In contrast, one of the variants in the Okanagan, ESSFdc2, had a low percentage of non-harvestable area, with much higher levels in the upper subalpine ESSFxcp (Fig. 2d). The greatest imbalance in representation of variants in nonharvestable areas was in Weyerhaeuser's tenure, ranging from only $0.7 \%$ and $2.3 \%$ in the two driest variants on southern Vancouver Island (CDFmm and CWHxm1) to $>60 \%$ of wetter (CWHvh2) and high-elevation $(\mathrm{MH})$ variants on northern Vancouver Island and Haida Gwai'i (Fig. 2a). Within a subzone on Weyerhaeuser's tenure, lower-elevation variants had poorer representation than higher variants (Fig 2; low elevation variants numbered "1," high elevation " 2 "; e.g., CWHvh1 versus CWHvh2).

Representation of site series or groupings of site series showed greater variability than variant-level representation, as expected from the smaller total area of these finer ecosystem types. Typically, the rarer site series at the extremes of the moisture gradient (xeric or hygric and subhydric), had higher percentages of non-harvestable area than the variant overall, while circum-mesic sites (submesic, mesic, subhygric) were underrepresented. The relative under-representation of circum-mesic sites was usually modest, however, simply because these site series compose most of a variant and so largely determine the overall average percentage for the variant. In the Arrow IFPA and in the sub-sample area with site series mapping on Weyerhaeuser's tenure, the site series with the poorest representation had approximately half the representation of the variant overall. (For example, if a variant was 
a.

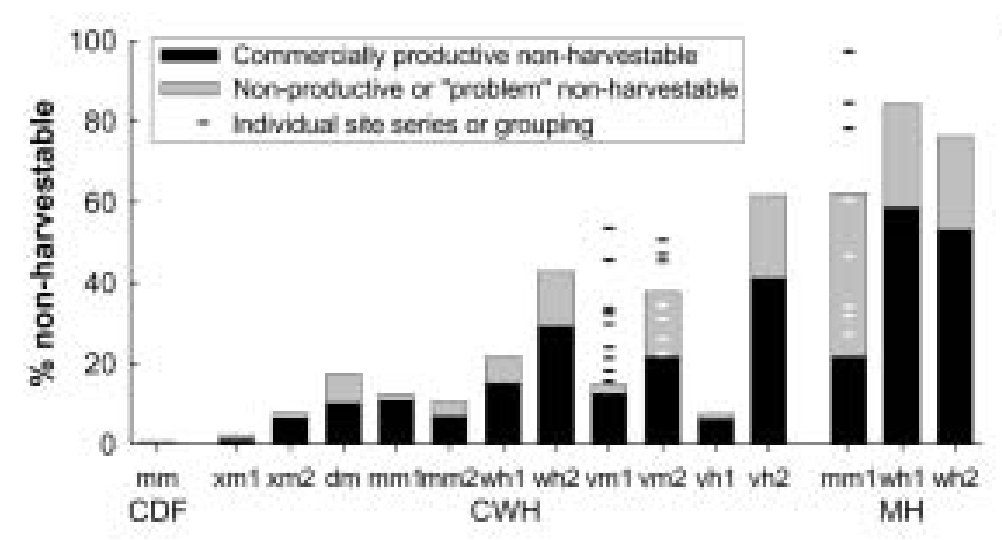

b.

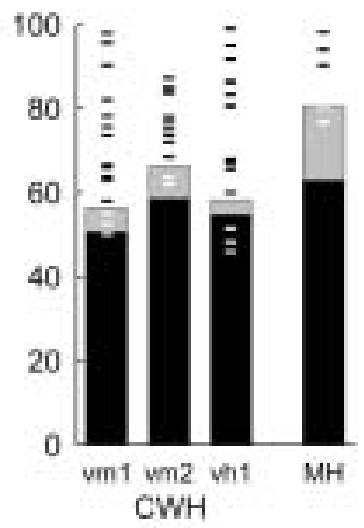

c.

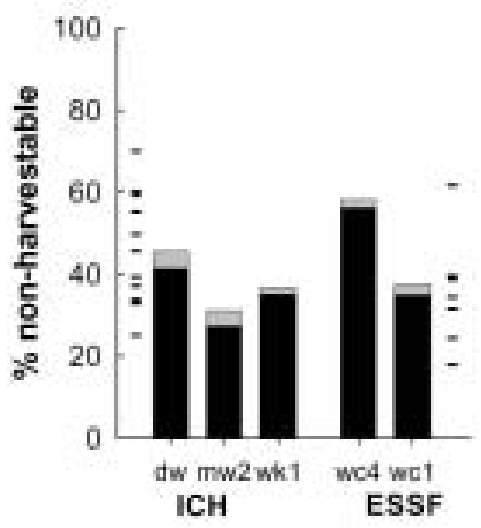

d.

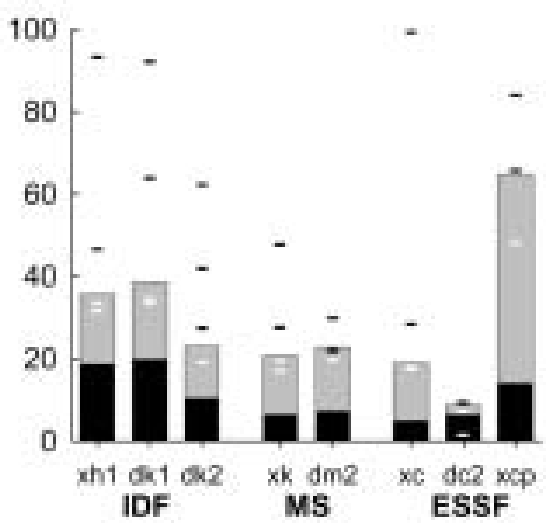

Fig. 2. Percent of forest in each biogeoclimatic variant that is non-harvestable, excluding (black) and including (grey) commercially nonproductive and "problem" forest types, for a) Weyerhaeuser's coastal B.C. tenure, b) Clayoquot Sound, c) Arrow IFPA and d) Okanagan drybelt study. See Appendix 1 for explanation of variant codes.

$40 \%$ non-harvestable, the poorest site series would be roughly 20\% non-harvestable). In Clayoquot Sound, representation of site series was an explicit goal in watershed planning, resulting in $>50 \%$ non-harvestable area in almost all site series.

Forest that was constrained from harvesting because it was a non-commercial stand type, "problem forest" or poor growing site comprised only $8.1 \%$ of the total non-harvestable area in the Arrow IFPA and $11.2 \%$ in Clayoquot Sound. However, on Weyerhaeuser's tenure, these poor sites were $39.3 \%$ of the total non-harvestable area and $65.3 \%$ in the Okanagan drybelt area. Considering just the commercially productive landbase, the overall percent non-harvestable dropped to $14.2 \%$ in Weyerhaeuser's tenure and $7.7 \%$ in the Okanagan drybelt, but with the same trends in representation across BEC variants (Fig. 2a, d). The abundance of these stands in the Okanagan reflects the prevalence of small-diameter suppressed lodgepole pine, along with slow-growing stands in upper subalpine regions. Most of the commercially non-productive sites on Weyerhaeuser's tenure are very old stands with volumes of merchantable timber considered too low to be commercially productive, though these stands are often valued highly for conservation. Confidence that organisms are well represented in the non-harvestable landbase is reduced when it is largely composed of problem forest types, anomalous stands or commercially non-productive areas.

With one exception, representation of high site index stands was lower than overall representation within a variant (Fig. 3). The difference was most pronounced in the higherelevation variants, which had high overall levels of representation on Weyerhaeuser's tenure. High site index stands, which are rare in these ecosystems, had low levels of representation, more typical of the drier, lower elevation variants. Under-representation of high site index stands also reduces confidence that non-harvestable areas capture the full range of species, because some organisms are associated with areas of high ecological productivity (Margules and Pressey 2000).

The contribution of inoperable areas to the non-harvestable landbase was examined in all studies because these areas could become harvestable with changes in technology 


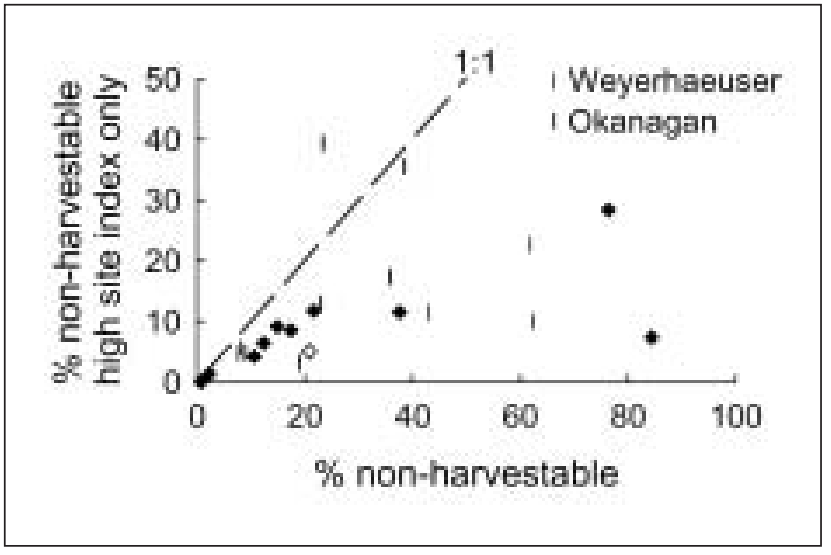

Fig. 3. Relationship between proportion of variants that are nonharvestable overall (X-axis) and within only high site index stands, for Weyerhaeuser's tenure (closed symbols) and Okanagan study (open symbols].

and markets. In most cases, inoperable areas were also constrained for other reasons, such as soil protection, terrain stability, riparian areas or visual landscapes. As a result, in Weyerhaeuser's tenure, the Okanagan study and Clayoquot Sound, representation of any variant would drop by less than $3 \%$ if inoperable areas became harvestable. Inoperable area makes a greater contribution by itself in the Arrow IFPA, where up to one-third of the non-harvestable area of some site series groupings is constrained only by operability.

\section{Edge/interior}

In Weyerhaeuser's tenure, only $7.8 \%$ of the non-harvestable area is $>200 \mathrm{~m}$ from a harvestable stand, and $61.0 \%$ is $<50$ $\mathrm{m}$ from a harvestable stand. Non-harvestable area $>200 \mathrm{~m}$ from a harvestable stand is lacking in the two driest variants, which have the lowest overall representation, mostly from narrow riparian reserves (Fig. 4a). Convoluted shapes of inoperable areas, steep slopes and sensitive soils reduce the amount of interior non-harvestable area in other variants with greater overall representation. Small harvestable patches embedded within larger non-harvestable areas also contribute to a disproportionately large amount of edge area on this tenure.

With a higher overall proportion of non-harvestable land, and larger, more contiguous areas, Clayoquot Sound had $60.3 \%$ of the non-harvestable area $>200 \mathrm{~m}$ from harvestable stands, and $21.2 \%$ within $50 \mathrm{~m}$. The interior and edge proportions were distributed similarly across the four variants (Fig. 4b).

In the Okanagan study, $23.2 \%$ of the non-harvestable forest was $>200 \mathrm{~m}$ from a harvestable stand, while $39.2 \%$ was within $50 \mathrm{~m}$. The lowest proportion of interior non-harvestable area was found in the ESSFdc2 variant, with low overall representation, and in the IDFxh1 and ESSFxcp variants (Fig. 4c), where constrained forest occurs in highly convoluted areas of inoperable or problem forest types. The Arrow IFPA had a similar $37.2 \%$ of the non-harvestable area within $50 \mathrm{~m}$ of the managed landbase, with relatively constant proportions across the different variants (not shown, because 200-m buffers were not used in the Arrow IFPA study).

\section{Additional contributions of proposed reserves}

Old Growth stewardship zones proposed by Weyerhaeuser make relatively little additional contribution to non-harvestable forest (Fig. 5a) because $60.5 \%$ of the area in these proposed zones is already non-harvestable. Old Growth zones were specifically located in existing large patches of oldgrowth forest to meet social desires for old-growth conservation; many of these old-growth patches have remained old forest because they were already largely constrained from timber harvesting.

In Clayoquot Sound, Eehmiis areas increase the non-harvestable area by $14.8 \%$, with a range of $7.6-19.4 \%$ across the four variants (Fig. 5b). The contribution of Eehmiis areas is more varied across individual site series. Of six site series with $<60 \%$ in the non-harvestable landbase, Eehmiis areas increase non-harvestable area by $>18 \%$ in three cases, but by $<8 \%$ in the other three (not shown). As large, contiguous patches, Eehmiis areas also increase interior area and reduce the proportion of non-harvestable forest within $200 \mathrm{~m}$ of harvestable stands from $39.8 \%$ to $20.6 \%$.

In the Okanagan study, parks proposed by a public landuse planning process would contribute non-harvestable land mostly in the ESSFxcp variant, already well-represented by non-harvestable area, and would not add any non-harvestable area to the poorly-represented ESSFdc2. In contrast, OGMAs proposed by the government would make a substantial contribution to non-harvestable area in ESSFdc2.

\section{Habitat structures and winter bird communities}

Mature non-harvestable stands in the ESSF zone had 39\% fewer snags and 57\% less CWD volume (Fig. 6) than mature stands in the harvestable landbase. Non-harvestable ESSF stands also tended to have lower densities of live trees, shorter trees, and more exposed mineral soil or rock. Habitat features in non-harvestable stands in ICH were more similar to harvestable stands in that zone.

Twenty-nine bird species were detected in the winter surveys. Species composition and relative abundances were similar in the harvestable and non-harvestable ESSF stands, given high variability. In the ICH, however, non-harvestable stands had $45 \%$ and $19 \%$ fewer detections overall than harvestable stands in the two winters, with substantial differences in a few species (e.g., brown creeper and red crossbill; Fig. 6).

\section{Discussion}

\section{Case studies}

The proportions of non-harvestable forest in the study areas exceed the amounts in official protected areas. For example, on Weyerhaeuser's tenure, an industrial operational area which does not include adjacent parks, $25.7 \%$ of the forest is non-harvestable area, compared to $17.2 \%$ of coastal B.C. that is in provincial and federal parks. Non-harvestable proportions are lower if we consider only commercially productive forest, but these levels also likely exceed the percentage of productive forest that is officially protected. Non-harvestable areas outside of parks can therefore have a substantial role in regional conservation, and accounting for the non-harvestable landbase becomes an important coarse-filter indicator for monitoring programs. Information on the ecological representativeness of non-harvestable areas helps in evaluating forest management options - including proposed new 

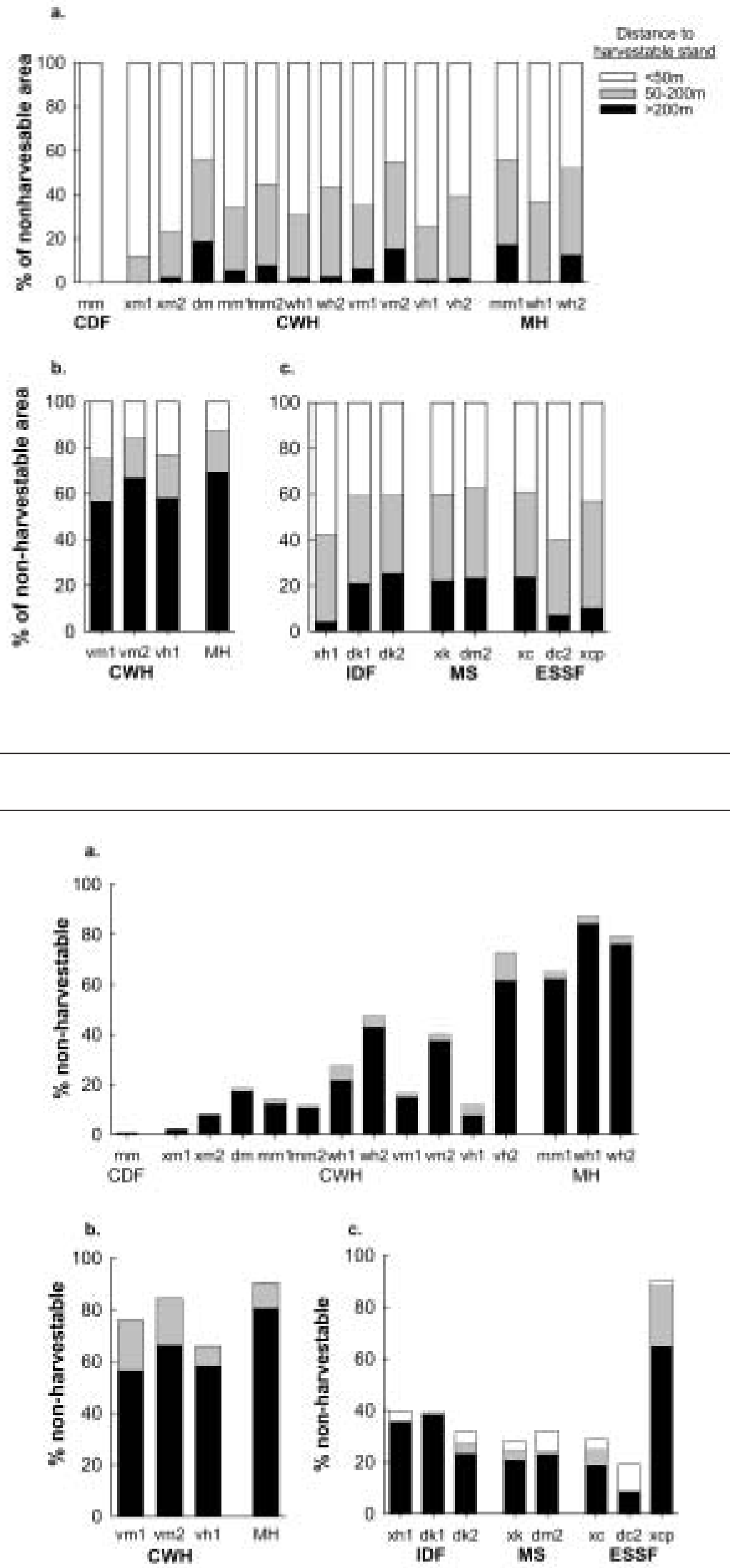


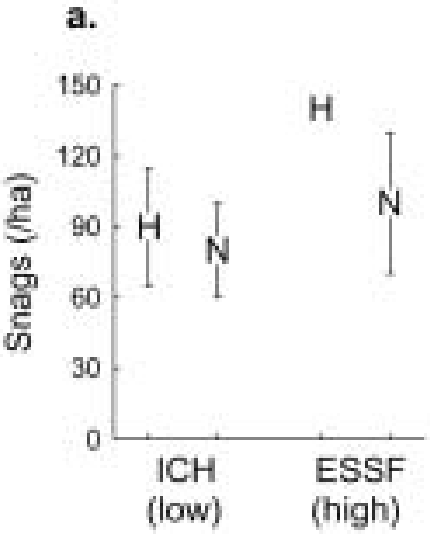

c.

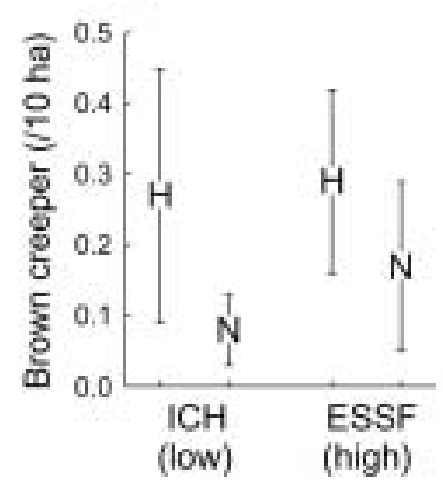

b.

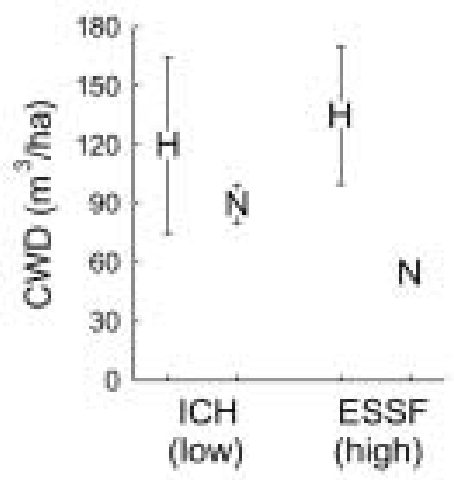

d.

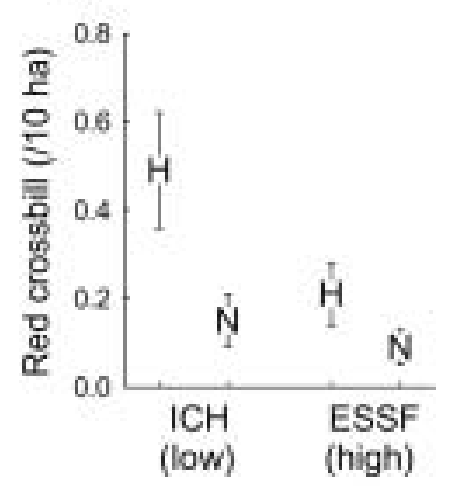

Fig. 6. Abundance of two habitat elements a) snags, and b] coarse woody debris (CWD), and relative abundance in winter of two bird species cl brown creepers and d) red crossbills in mature harvestable $(H)$ and non-harvestable (N) stands in Interior Cedar - Hemlock (ICH) and Engelmann Spruce - Subalpine Fir (ESSF) forest in Arrow IFPA. Error bars are 1 S.E. reserves, stand-level retention levels and landscape plans and focusing more expensive fine-filter monitoring into the most extensively managed ecosystems.

The analysis of Weyerhaeuser's coastal B.C. tenure showed that a clear priority is to address the poor levels of representation of low-elevation, dry variants on southern Vancouver Island. This major bias in representation follows a global pattern of poor protection of lowland and drier ecosystem types (e.g., Awimbo et al. 1996, Powell et al. 2000, Sierra et al. 2002). Old Growth stewardship zones established by the company currently do not address this problem because they were located to protect socially-valued large areas of old forest, which no longer exist on southern Vancouver Island. Smaller Old Growth zones or other discretionary reserves could be established in this area, but a fundamental conflict for the company is that much of this forest is highly productive private land and the most profitable operating area. One option being explored is to use commercial thinning of the dominant second-growth stands to promote development of oldforest structures, and then to sell conservation covenants to recover the remaining costs of taking this land out of production (W. Beese ${ }^{6}$, personal communication). However, there

\footnotetext{
${ }^{6}$ North Island Timberlands, Weyerhaeuser. 65 Front St., Nanaimo, B.C. V9R 5H9.
}

has been little interest in this idea from the conservation community. Another option to mitigate the poor representation is to increase retention levels in harvested stands in this area, though this has less certain ecological benefits and also entails economic costs. To date, the main result of monitoring representation on Weyerhaeuser's tenure has been to focus more intensive stand-level monitoring of habitat structures and organisms in poorly represented ecosystems, where successful stand-level management of biodiversity is being relied upon most heavily (Kremsater et al. 2003).

In the Arrow IFPA, variants were fairly equitably represented in non-harvestable areas because of a diversity of harvesting constraints. However, the GIS monitoring did identify several relatively poorly represented groupings of site series, which have been used by the IFPA partners as one set of indicators to evaluate reserve systems proposed in landscape plans. This was a useful contribution to simplifying the complexity of one important ecological aspect of land planning.

The Okanagan study indicated that one variant, ESSFdc2, was a priority for improving representation within this relatively small area, and that OGMAs proposed by government would make a substantial improvement. Parks proposed by a public land-use process would make little contribution to ecological representation in this area. Decisions on which sets of proposed reserves to implement, however, are clearly based on many values, with ecological representation being an indi- 
cator of only one of these values. Recreation, economics and aesthetics are important public values that often favour locating reserves in subalpine parkland, which is already well-represented by non-harvestable areas.

The Clayoquot Sound study also highlighted the role of different values in interpreting monitoring results. Keeping Eehmiis areas unharvested would substantially increase ecological representation in the Sound, helping to meet high ecological objectives in this area. On the other hand, non-harvestable area is already much higher in Clayoquot Sound than in other parts of the region, particularly southern Vancouver Island. With limited resources for conservation from government and environmental groups, there is a trade-off between increasing non-harvestable areas in the highly valued Clayoquot Sound, and improving representation outside the Sound for broader regional biodiversity. Again, Eehmiis areas are valued for many reasons beyond their contribution to regional representation of ecosystems.

One common finding in the case studies was the prevalence of non-harvestable area that is near harvestable stands. With the exception of Clayoquot Sound, typically half of the non-harvestable forest is within $50 \mathrm{~m}$ of a harvestable stand, and less than one-quarter is $>200 \mathrm{~m}$ from a harvestable edge. Although these adjacent stands have not necessarily been harvested, they will likely be at some point in the harvest rotation. Edge effects could then impact on the assumed ecological contribution of the non-harvestable areas, especially maintenance of poorly-known species and the processes they depend on, as well as the role of non-harvestable areas as benchmarks. Potential edge effects can be mitigated in several ways. Retention patches in harvested stands can be located adjacent to non-harvestable areas as buffers. Weyerhaeuser has begun to implement this option, especially with riparian reserves, which are a main component of the non-harvestable landbase in several of the variants with little interior non-harvestable forest. Stands with higher overall retention levels can also be used to buffer adjacent non-harvestable areas. In some cases, foregoing harvesting in a few small harvestable areas embedded in larger non-harvestable areas would produce disproportionately large increases in the amount of non-harvestable interior. At a larger scale, harvest locations and timing can be planned to maintain older managed stands adjacent to at least part of each non-harvestable area through time, rather than isolating non-harvestable areas with young stands.

We emphasize that our results are based on the non-harvestable landbase as currently defined. This will change with changes in legislation, policy, technology and markets. Some of the policy changes may themselves be motivated by improving ecological representation. Monitoring of ecological representation in non-harvestable areas is therefore an ongoing process.

Monitoring ecological representation in non-harvestable areas Ecological representation in non-harvestable areas has received considerable attention from forest companies, government ministries, and environmental groups, and is increasingly used as a coarse-filter indicator in biodiversity monitoring programs. Our experience with the case studies suggests several general points for programs intending to monitor ecosystem representation in non-harvestable areas.

\section{Regional analyses}

The boundaries for the studies reviewed in this paper were determined by company operating areas or government administrative units. Interpretations of results were often made tentative by uncertainty about the situation outside the study area. An ecosystem with poor representation locally might be well-represented elsewhere, or vice versa. Some of the case studies partially addressed this by measuring "responsibility" (following Dunn et al. 1999), the proportion of the total extent of an ecosystem that was within the study area (results not presented). Emphasis in reporting and responding to results was placed on high responsibility ecosystems.

However, land use planning and the monitoring that supports it are most effective at larger regional scales (Noss et al. 1999). Representation should ideally be evaluated regionally, analyzing representation of each ecosystem type in unmanaged areas across all tenures or administrative units, including private lands, public lands and protected areas. Data coordination is the main limitation to regional analyses. Information on harvest constraints is often held by individual companies and various government ministries. Ecosystem mapping is often patchy, and classifications need to be coordinated where ecosystems cross jurisdictions. Overcoming these limitations to allow regional analyses would provide more ecologically meaningful information for any management area within the region. Regional monitoring would also help in decisions about allocation of resources, such as the trade-offs between conservation within Clayoquot Sound and broader regional representation.

\section{Defining ecosystems}

A major assumption of representation analyses is that the ecosystem types truly represent the full range of organisms of concern (Belbin 1993, Pressey et al. 2000, Mac Nally et al. 2002). The B.C. BEC system is a convenient hierarchical classification reflecting climatic, geographic and vegetation surrogates, but there is little information on how well the different units represent the ecological distribution of many organisms. An important empirical question is whether any species are restricted to single site series, or whether groupings of similar site series are appropriate. One recommendation is that the many ongoing projects inventorying and monitoring organisms should record basic ecosystem classifications for survey sites. Once compiled, these data could provide a better empirical test of suitable ecosystem units.

An additional concern with using general ecosystem classifications like B.C.'s BEC system is that they tend to differentiate special ecosystem types poorly. Rare forest types important to some organisms may not be recognized in the classification system. An example in B.C. is forest on karst formations, some of which have been mapped and reserved to protect associated cave systems (Province of British Columbia 1994). Mapping of other special forested ecosystems is typically spotty, often associated with road access and therefore probably biased towards the harvestable landbase. Increased effort for broad-scale mapping of these rare ecosystem types would allow an important additional refinement to representation analyses.

More generally, it is not clear what other available ecosystem descriptors should be included in analyses. The case stud- 
ies compared representation with and without commercially non-productive or problem forest types, and examined high site index forests in two cases. However, there is no clear evidence on whether species are restricted to only part of a productivity gradient within a site series, or what cutoff points should be used. Similarly, the BEC system partially reflects variation due to geographic location, slope, elevation and topography, but again evidence is lacking on whether species further distinguish along these gradients or other variables within site series. This empirical question of how organisms distinguish ecosystem types would be particularly important for representation analyses that rely on coarser ecosystem classifications, or where ecosystem types cover large geographic areas. In these cases, other surrogate variables such as elevation, aspect, topography and geographic location could be included. Projects to monitor ecosystem representation should at least be coordinated with broader programs monitoring organisms across ecosystem types.

\section{Testing representation of non-harvestable areas}

Comparisons of mature (100- to 140-year-old) harvestable and non-harvestable stands in the Arrow IFPA suggested that non-harvestable stands may have substantially different habitat elements from harvestable stands in the same site series grouping, and that at least some organisms may also differ. Although these studies showed high variation among stands, and winter birds are clearly a small subset of all organisms, the results suggest caution in assuming that non-harvestable areas are truly representative of the habitats and organisms they are intended to help maintain. The results emphasize that GIS analyses of ecosystem representation are only intended as a coarse-filter indicator, to be used in conjunction with more detailed monitoring of habitat structures and organisms (Lindenmayer et al. 2000, Quinby 2001, Mac Nally et al. 2002). This point can easily be forgotten given the ease of GIS compared to the expense and difficulty of field monitoring.

\section{Including other disturbances}

In our four case study areas, forestry is the dominant land-use activity. Other resource development, such as oil and gas exploration or mineral development, may be more important elsewhere. The availability of land for these other uses would have to be included in the analysis; areas constrained from forestry will clearly not provide long-term contributions as non-harvestable areas if they are developed for some other resource. Salvage of natural disturbances is another activity that can reduce the contribution of non-harvestable areas, particularly because many species are dependent on unsalvaged natural disturbances (Lindenmayer et al. 2004). Representation analyses should ideally distinguish whether non-harvestable stands are available for salvage, but this information is typically not available prior to individual disturbances.

\section{Updating results}

Non-harvestable areas are intended to make a long-term contribution as areas not subject to timber harvest. Current age of non-harvestable stands or adjacent managed forest is not critical information with the long-term perspective of this coarse-level indicator. This may suggest that analyses of nonharvestable area only need to be done once in a monitoring program. However, our experience with the case studies in B.C. shows that harvesting constraints can change frequently, with large effects on what constitutes the non-harvestable landbase. For example, our first analysis of Weyerhaeuser's tenure in 2000 found $38.3 \%$ non-harvestable forest, while the current analysis showed $27.5 \%$. The difference was due to a re-assessment by the company of inoperable and commercially non-productive areas for timber supply analysis, and changes in B.C.'s Forest Practices Code. In the Okanagan area, widespread salvage of trees killed by mountain pine beetle will likely affect some previously non-harvestable areas. Monitoring of representation should be ongoing, updated whenever changes in regulations, practices, technology or markets substantially modify the non-harvestable landbase. This ongoing monitoring is an important part of assessing what the effects of those changes are, ideally as an input before decisions are made that affect the non-harvestable landbase.

\section{Acknowledgements}

We thank Weyerhaeuser, Iisaak, CanFor, B.C. Ministry of Forests and B.C. Ministry of Sustainable Resource Management for landbase information, Aaron Fujikawa, Arnold Moy, Steven Northway and Chris Steeves for conducting the GIS analysis. Funding for the case studies was provided by Weyerhaeuser, Arrow IFPA, WWF Canada, B.C. Ministry of Forests and B.C.'s Forest Investment Account.

\section{References}

Arcese, P. and A.R.E. Sinclair. 1997. The role of protected areas as ecological baselines. J. Wildl. Manage. 61: 587-602.

Austin, M.P. and C.R. Margules. 1986. Assessing representativeness. In M.B. Usher (ed.). Wildlife conservation evaluation. pp. 45-67. Chapman and Hall, London, U.K.

Awimbo, J.A., D.A. Norton and F.B. Overmars. 1996. An evaluation of representativeness for nature conservation, Hokitika Ecological District, New Zealand. Biological Conserv. 75: 177-186.

Beier, P. and R.F. Noss. 1998. Do habitat corridors provide connectivity? Conserv. Biol. 12: 1241-1252.

Belbin, L. 1993. Environmental representativeness: regional partitioning and reserve selection. Biological Conserv. 66: 223-230.

Boyland, M., J. Nelson and F.L. Bunnell. 2004. Creating land allocation zones for forest management: a simulated annealing approach. Can. J. For. Res. 34: 1669-1682.

Clayoquot Sound Scientific Panel. 1995. Sustainable ecosystem management in Clayoquot Sound: planning and practices. Government of British Columbia, Victoria, B.C.

DeVelice, R.L., J.W. DeVelice and G.N. Park. 1988. Gradient analysis in nature reserve design: a New Zealand example. Conserv. Biol. 2: 206-217.

DeVelice, R.L. and J.R. Martin. 2001. Assessing the extent to which roadless areas complement the conservation of biological diversity. Ecol. Applications 11: 1008-1018.

Dunn, E.H., D.J.T. Hussell and D.A. Welsh. 1999. Priority-setting tool applied to Canada's landbirds based on concern and responsibility for species. Conserv. Biol. 13: 1404-1415.

Green, R.N. and K. Klinka. 1994. A field guide to site identification and interpretation for the Vancouver Forest Region. B.C. Min. For. Res. Branch, Victoria, B.C.

Harris, L.D. 1988. Edge effects and conservation of biotic diversity. Conserv. Biol. 2: 330-332. 
Herbers, J.R., R. Serrouya and K.A. Maxcy. 2004. Effects of elevation and forest cover on winter birds in mature forest ecosystems of southern British Columbia. Can. J. Zool. 82: 1720-1730.

Johnson, R.K. 1999. Regional representativeness of Swedish reference lakes. Environmental Manage. 23: 115-124.

Kati, V., P. Devillers, M. Dufrene, A. Legakis, D. Vokou and P. Lebrun. 2004. Hotspots, complementarity or representativeness? Designing optimal small-scale reserves for biodiversity conservation. Biological Conserv. 120: 471-480.

Kremsater, L. L. and F.L. Bunnell. 1999. Edge effects: Theory, evidence and implications for management of western North American forests. In J.A. Rochelle, L.A. Lehmann and J. Wisniewski (eds.). Forest fragmentation: Wildlife and management implications. pp. 117-153. Brill, Leiden, Netherlands.

Kremsater, L., F. Bunnell, D. Huggard and G. Dunsworth. 2003. Indicators to assess biological diversity: Weyerhaeuser coastal British Columbia. For. Chron. 79: 1-12.

Lindenmayer, D.B., R.B. Cunningham, C.F. Donnelly and R. Lesslie. 2002. On the use of landscape indices as ecological indicators in fragmented forests. For. Ecol. Manage. 155: 319-335.

Lindenmayer, D.B., D.R. Foster, J.F. Franklin, M.L. Hunter, R.F. Noss, F.A. Schmiegelow and D. Perry. 2004. Salvage harvesting after natural disturbance. Sci. 303: 1303.

Lindenmayer, D.B., C.R. Margules and D.B. Botkin. 2000. Indicators of biodiversity for ecologically sustainable forest management. Conserv. Biol. 14: 941-950.

Lloyd, D., K. Angove, G. Hope and C. Thompson. 1990. A guide to site identification and interpretation for the Kamloops Forest Region. B.C. Min. For., Land Manage. Handb. 23. Victoria, B.C.

Mac Nally, R., A.F. Bennett, G.W. Brown, L.F. Lumsden, A. Yen, S. Hinkley, P. Lillywhite and D. Ward. 2002. How well do ecosystembased planning units represent different components of biodiversity? Ecol. Applications 12: 900-912.

Margules, C.R. and R.L. Pressey. 2000. Systematic conservation planning. Nature 405: 243-253.

Margules, C.R. and J.L. Stein. 1989. Patterns in the distributions of species and the selection of nature reserves: an example from Eucalyptus forests in south-eastern New South Wales. Biol. Conserv. 50: 219-238.

Margules, C. and M.B. Usher. 1981. Criteria used in assessing wildlife conservation potential: a review. Biol. Conserv. 21: 79-109. McKenzie, N.L., L. Belbin, C.R. Margules and G.J. Keighery. 1989. Selecting representative reserve systems in remote areas: a case study in the Nullarbor Region, Australia. Biol. Conserv. 50: 239-261.

Mendel, L.C. and J.B. Kirkpatrick. 2002. Historical progress of biodiversity conservation in the protected-area system of Tasmania, Australia. Conserv. Biol. 16: 1520-1529.

Noss, R.F. 1999. Assessing and monitoring forest biodiversity: a suggested framework and indicators. For. Ecol. Man. 115: 135-146.
Noss, R.F., J.R. Strittholt, K. Vance-Borland, C. Carroll and P.A. Frost. 1999. A conservation plan for the Klamath-Siskiyou ecoregion. Natural Areas J. 19:392-411.

Pojar, J., K. Klinka and D.V. Meidinger. 1987. Biogeoclimatic ecosystem classification in British Columbia. For. Ecol. Manage. 22: 119-154.

Powell, G.V.N., J. Barborak and M. Rodrigues. 2000. Assessing representativeness of protected natural areas in Costa Rica for conserving biodiversity: a preliminary gap analysis. Biol. Conserv. 93: 35-41. Pressey, R.L. 2004. Conservation planning and biodiversity: assembling the best data for the job. Cons. Biol. 18: 1677-1681.

Pressey, R.L., T.C. Hager, K.M. Ryan, J. Schwarz, S. Wall, S. Ferrier and P.M. Creaser. 2000. Using abiotic data for conservation assessments over extensive regions: quantitative methods applied across New South Wales, Australia. Biol. Conserv. 96: 55-82.

Province of British Columbia. 1994. Cave/karst management handbook for the Vancouver Forest Region. B.C. Min. For., Victoria, B.C. Quinby, P.A. 2001. Scale of ecological representation: a case study of old-growth forest conservation in Temagami, Ontario, Canada. Natural Areas J. 21: 216-228.

Richards, W.H., D.O. Wallin and N.H. Schumaker. 2002. An analysis of late-seral forest connectivity in western Oregon, U.S.A. Conserv. Biol. 16: 1409-1421.

Sætersdal, M. and H.J.B. Birks. 1993. Assessing the representativeness of nature reserves using multivariate analysis: vascular plants and breeding birds in deciduous forests, western Norway. Biol. Conserv. 65: 121-132.

Scott, J.M., F.W. Davis, R.G. McGhie, R.G. Wright, C. Groves and J. Estes. 2001a. Nature reserves: do they capture the full range of America's biological diversity? Ecol. Applications 11: 999-1007.

Scott, J.M., M. Murray, R.G. Wright, B. Csuti, P. Morgan and R.L. Pressey. 2001b. Representation of natural vegetation in protected areas: capturing the geographic range. Biodivers. Conserv. 10: 1297-1301.

Sierra, R., F. Campos and J. Chamberlin. 2002. Assessing biodiversity conservation priorities: ecosystem risk and representativeness in continental Ecuador. Landsc. Urban Planning 59: 95-110.

Stokland, J.N. 1997. Representativeness and efficiency of bird and insect conservation in Norwegian boreal forest reserves. Conserv. Biol. 11: 101-111.

Strittholt, J.R. and D.A. DellaSala. 2001. Importance of roadless areas in biodiversity conservation in forested ecosystems: case study of the Klamath-Siskiyou ecoregion of the United States. Conserv. Biol. 15: 1742-1754.

UNESCO. 1974. Task force on criteria and guidelines for the choice and establishment of biosphere reserves. Man and the Biosphere Report 22: 1-61.

Van Wagner, C.E. 1968. The line intercept method in forest fuel sampling. For. Sci. 14: 20-26. 
Appendix 1. Definitions of biogeoclimatic zones and variants used in the case studies.

In coastal zones, subzones are defined by moisture regime and oceanic effects on the temperature regime. Variants within the coastal subzones differentiate lower and higher elevation ecosystems, except in the highest-elevation Mountain Hemlock zone where variants distinguish exposure to prevailing moisture-laden winds. See Green and Klinka (1994) for details of climate, soil, geographic distribution and vegetation types.

For the zones in the $\mathrm{BC}$ Interior, subzones are defined by moisture and temperature regimes. Variants within the Interior subzones describe geographic variation in the ecosystems. See Lloyd et al. (1990) for details of climate, soil, geographic distribution and vegetation types.

\section{Zone}

Subzone

Variant

CDF - Coastal Douglas-Fir (dry, lowest elevation on coast)

$\mathrm{mm}$ - moist maritime

[none differentiated]

CWH - Coastal Western Hemlock (dominant zone on coast)

$$
\begin{aligned}
& \text { xm - very dry maritime } \\
& \mathrm{dm} \text { - dry maritime (mainland) } \\
& \text { mm - moist maritime } \\
& \text { wh - wet hypermaritime } \\
& \text { vm - very wet maritime } \\
& \text { vh - very wet hypermaritime }
\end{aligned}
$$

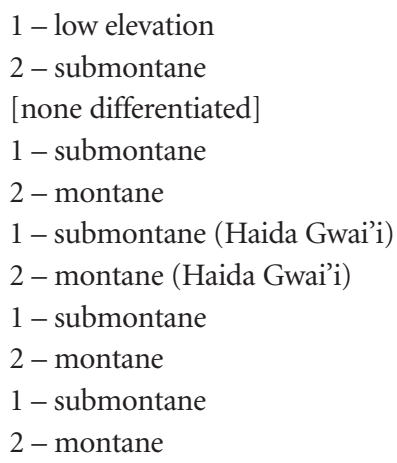
$\mathrm{MH}$ - Mountain Hemlock (high elevations on coast)
mm - moist maritime
wh - wet hypermaritime

1 - windward

1 - windward (Haida Gwai'i, north coast)

2 - leeward (Haida Gwai'i, north coast)

IDF - Interior Douglas-Fir (dry, lower elevation in BC interior)
xh - very dry hot
1 - Okanagan
dk - dry cool
1 - Thompson
2 - Cascade
MS - Montane Spruce (mid-elevation, often seral stands, in BC interior)
xk - very dry cool
dm - dry mild
ICH - Interior Cedar - Hemlock (wet, lower elevation in BC interior)
dw - dry warm
mw - moist warm
wk - wet cool

[none differentiated]

2 - Thompson

[none differentiated]

2 - Shuswap

1 - Wells Gray

ESSF - Engelmann Spruce - Subalpine Fir (higher elevation in BC interior)

$$
\begin{aligned}
& \text { xc - very dry cold } \\
& \text { xcp - very dry cold parkland } \\
& \text { dc - dry cold } \\
& \text { wc - wet cold }
\end{aligned}
$$

[none differentiated]

[none differentiated]

2 - Thompson

1 - Columbia

4 - Selkirk 